\title{
PERANAN FILSAFAT HUKUM DALAM MEWUJUDKAN KEADILAN
}

\author{
Handayani $^{1}$, Johannes ${ }^{2}$, Kiki $^{3}$ \\ ${ }^{1}$ Fakultas Hukum, Universitas Tarumanagara Jakarta \\ Email: handayani205150109@stu.untar.ac.id \\ ${ }^{2}$ Fakultas Hukum, Universitas Tarumanagara Jakarta \\ ${ }^{3}$ Fakultas Hukum, Universitas Tarumanagara Jakarta
}

\begin{abstract}
The writer in this paper tried to investigate and describe the philosophical thoughts of the role of Law Philosophy in to realize justice. However, if there are questions about justice, could not be determined what measures are use to determine something is fair or not. Various answers about justice usually never or rarely satisfying so that continues to be debated, so it can be concluded that the various formulations so of justice if a relative statement. This issue Ultimately encourages many people to take a shortcut by submitting formulation or justice to the legislators and judges who will formulate it based on their own considerations.
\end{abstract}

Keywords: Philosophy Law, Justice, The Concept of Justice

\begin{abstract}
ABSTRAK
Penulis dalam makalah ini mencoba untuk menyelidiki dan menggambarkan pemikiran filosofis dari peran Filsafat Hukum dalam mewujudkan keadilan. Namun, jika ada pertanyaan tentang keadilan, tidak bisa ditentukan langkah apa yang digunakan untuk menentukan sesuatu itu adil atau tidak. Berbagai jawaban tentang keadilan biasanya tidak pernah atau jarang memuaskan sehingga terus diperdebatkan, sehingga dapat disimpulkan bahwa berbagai rumusan keadilan jadi kalau pernyataan relatif. Masalah ini pada akhirnya mendorong banyak orang untuk mengambil jalan pintas dengan menyerahkan formulasi atau keadilan kepada para legislator dan hakim yang akan merumuskannya berdasarkan pertimbangan mereka sendiri.
\end{abstract}

Kata kunci: Hukum Filsafat, Keadilan, Konsep Keadilan

\section{PENDAHULUAN}

Ukuran mengenai keadilan seringkali ditafsirkan berbeda-beda. Keadilan itu sendiripun bermacammacam, dalam berbagai bidang, misalnya ekonomi, maupun hukum. Berbicara mengenai keadilan hal ini senantiasa menjadi topik yang utama dan menarik, karena selalu berhubungan dengan penyelesaian yang berhubungan dengan penegak hukum. Banyaknya kasus hukum yang tidak dapat di selesaikan atau di putuskan dengan adil karena di tarik dalam masalah politik. Kebenaran hukum dan keadilan dimanipulasi dengan cara yang sistematik sehingga peradilan tidak memberikan putusan adil karena tidak melalui prosedur yang benar, tindakan pengadilan seringkali tidak bijak karena tidak memberi kepuasan pada masyarakat.

Sebagai contoh dapat diilustrasikan dalam penerapan beberapa putusan pengadilan yang sering dianggap mematikan rasa keadilan masyarakat. Misalnya dalam putusan bebas yang dijatuhkan oleh majelis hakim Pengadilan Negeri Jakarta Selatan beberapa waktu lalu, terhadap terdakwa dalam kasus korupsi Bank Mandiri yang dituntut oleh jaksa 20 penjara, mengundang berbagai pro dan kontra (Amin, 2017). Contoh lain dalam kasus BLBI, kepastian hukum dan keadilan dalam 
kebijakan hukum yang di ambil pemerintah telah menimbukan ketidakadilan bagi sebagian tersangka/terdakwa serta masyarakat luas, bahkan tampak diskriminatif, dan kasus-kasus lainnya.

Seperti diketahui istilah keadilan senantiasa dipertentangkan dengan istilah ketidakadilan. Dimana ada konsep keadilan maka di situ pun ada konsep ketidakadilan. Oleh karena itu, filsafat hukum relevan untuk membangun kondisi hukum yang sebenarnya, sebab tugas filsafat hukum adalah menjelaskan nilai dasar hukum secara filosofis yang mampu memformulasikan cita-cita keadilan, ketertiban di dalam kehidupan yang relevan dengan pernyataan-kenyataan hukum yang beralku, bahkan merubah secara radikal dengan tekanan hasrat manusia melalu paradigma hukum baru guna memenuhi perkembangan hukum pada suatu masa dan tempat tertentu.

Mengenai fungsi Filsafat Hukum, Roscoe Pound (1972: 3) menyatakan, bahwa ahli filsafat berupaya untuk memecahkan persoalan tentang gagasan untuk menciptakan suatu hukum yang sempurna yang harus berdiri teguh selama-lamanya, kemudian membuktikan kepada umat manusia bahwa hukum telah selesai ditetapkan, kekuasaanya tidak dipersoalkan lagi.

Filsafat ilmu hukum, ada yang menyebutnya dengan istilah filsafat hukum, sesungguhnya merupakan sub dari cabang filsafat manusia, yang disebut etika atau filsafat manusia. Oleh karena filsafat ilmu hukum maupun filsafat hukum adalah ilmu yang mempelajari hukum secara filosofis maka objeknya adalah hukum. Mengenai pembedaan ilmu hukum maupun hukum, Curzon menyebutnya bahwa ilmu hukum mencakup dan membicarakan segala hal yang berhubungan dengan hukum. Demikian luasnya masalah yang mencakup oleh ilmu ini, sehingga sempat memancing pendapat orang untuk mengatakan, bahwa "batas-batasnya tidak ditentukan" (Rahardjo, 2000).

\section{PEMBAHASAN}

\section{Filsafat Ilmu Hukum dan Tujuan Hukum}

Untuk mengetahui kerangka keseluruhan filsafat perlu diketahui terlebih dahulu apa yang dimaskuh dengan filsafat itu, "Filsafat" dalam bahasa latin dikenal dengan sebutan Philosophy (Inggris), Philosphie (Perancis dan Belanda), filosofie, wijsbegeerte (belanda), Philosohia (Latin). Kata "filsafat ini diambil dari bahasa Arab, Yaitu "falsafah". Secara etimologis filsafat atau falsafah itu sendiri berasal dari bahasa Yunani, yaitu Philos atau filo yang artinya cinta (dalam arti seluasluasnya), dan sophia atau sofia yang artinya kebijaksanaan. Jadi dari sudut asal-asul katanya, filsafat dapat diartikan sebagai cinta akan kebijaksanaan (Darmodiharjo, 2006).

Satjipto Rahardjo selanjutnya menambahkan, sebagaimana halnya dengan setiap cabang ilmu, maka ilmu hukum ini mempunyai objeknya sendiri, yaitu hukum, betapa ilmu hukum itu mencakup bidang yang luas sekali. Sifat ini merupakan akibat dari beban yang dipikulnya, yaitu memaparkan di hadapan kita fenomena hukum dalam hakikatnya, sifat-sifatnya, fungsinya dalam masyarakat sehingga oleh karena itulah bisa dimengerti, mengapa ia mengandung pikiran dan penjelasan yang cukup beragam, baik yang falsfati, teknik maupun sosiologis (Rahardjo, 2000).

Di dalam kepustakaan hukum, ilmu hukum ini dikenal dengan nama, jurisprudence, berasal dari kata jus, juris, yang artinya adalah hukum atau hak; prudensi berarti melihat ke depan atau mempunyai keahlihan. Arti yang umum dari jurisprudence ini adalah ilmu yang mempelajari hukum, Tetapi orang juga mengenal tiga yang lain. Parah penulis Inggris memakinya dalam anatomi perbandingan sistem-sistem hukum yang sudah maju. Para penulis Prancis mengartikanya sebagai 
kecenderungan dari putusan yang diambil oleh pengadilan-pengadilan. Dibeberapa negara lain, terutama Amerika Serikat, kata itu dipakai sinonim dari hukum itu sendiri (Rahardjo, 2000). Dari penjelasan di atas, maka jelaslah pembedaan pemakaian filsafat ilmu hukum maupun filsafat hukum terletak hanya pada tataran istilah saja, tanpa maksud memilah dan membedakanya secara pokok krusial, yang sebenarnya keduanya mempelajari filsafat yang mempunya objek hukum.

Para ilmuwan dan filosof memberikan pengertian keadilan berbeda-beda sesuai dengan pandangan dan tujuan:

- Artistoteles, Keadilan adalah kebajikan yang berkaitan dengan hubungan antar manusia: keadilan legalis, distributif dan komutatif.

- Thomas Aquinas, keadilan terbagi 2 yaitu keadilan umum (justitia generalis dan keadilan khusus (justitis specialis)

- W. Friedmann, keadilan yang diformulasikan Artistoteles merupakan kontribusi pengembangan filsafat hukum, beliau membedakan keadilan menjadi tiga: keadilan hukum, keadilan alam dan keadilan abstrak dan kepatutan.

- Notohamidjojo, membagi eadilan menjadi 3 yaitu keadilan kreatif (iustitia creativa), keadilan protektif (iustitia protetiva) dan keadilan sosial (iustitia socia)

- Rouscoe Poud, keadilan 2 bagian: keadilan bersiat yudicial dan keadilan administratif

- John Rawl, keadilan adalah keadaan keseimbangan antara kepentingan pibadi dan kepentingan bersama (Darmodiharjo, 2006).

Korelasi antara filsafat, hukum dan keadilan sangat erat, karena terjadi tali temali antara kearifan, norma dan keseimbangan hak dan kewajiban. Hukum tidak dapat dipisahkan dengan masyarakat dan negara, materi hukum digali, dibuat dari nilai-nilai yang terkandung dalam bumi pertiwi yang berupa kesadaran dan cita hukum (rechtidee), cita moral, kemerdekaan individu dan bangsa perikemanusiaan, perdamaian, cita politik dan tujuan negara. Hukum mencerminkan nilai hidup yang ada dalam masyarakat yang mempunyai kekuatan berlaku secara yuridis, sosiologis dan filosofis. Hukum yang hidup pada masyarakat bersumber pada Hukum Positif, yaitu:

1. Undang-undang (Constitutional)

2. Hukum kebiasaan (Costumary of law)

3. Perjanjian Internasional (International treaty)

4. Keputusan hakim (Jurisprudence)

5. Doktrin (Doctrine)

6. Perjanjian (Treaty)

7. Kesadaran hukum (Consciousness of law) (Sudikno M, 1988: 28).

Dari pernyataan diatas, harus di akui bahwa hukum tanpa keadilan akan terjadi kesewenangwenangan. Sebenarnya keadilan dan kebenaran merupakan nilai kebajikan yang paling utama, sehingga nilai-nilai ini tidak bisa di tukar dengan nilai apapun.

hubungan antara filsafat, hukum dan keadilan, dengan filsafat sebagai induk ilmu (mother of science), adalah untuk mencari jalan keluar dari belenggu kehidupan secara rational dengan menggunakan hukum yang berlaku untuk mencapai keadilan dalam hidupnya. Peranan filsafat tak pernah selesai, tidak pernah berakhir karena filsafat tidak menyelidiki satu segi tetapi tidak terbatas 
objeknya, namun filsafat tetap setia kepada metodenya sendiri dengan menyatakan semua di dunia ini tidak ada yang abadi yang tetap hanya perubahan, jadi benar filsafat ilmu tanpa batas. Filsafat memiliki objek, metode, dan sistematika yang bersifat universal.

Filsafat hukum memfokuskan pada segi filosofisnya hukum yang berorientasi pada masalahmasalah fungsi dan filsafat hukum itu sendiri yaitu melakukan penertiban hukum, penyelesaian pertikaian, pertahankan dan memelihara tata tertib, mengadakan perubahan, pengaturan tata tertib demi terwujudnya rasa keadilan berdasarkan kaidah hukum abstrak dan konkrit. Pemikiran filsafat hukum berdampak positif sebab melakukan analisis yang tidak dangkal tetapi mendalam dari setiap persoalan hukum yang timbul dalam masyarakat atau perkembangan ilmu hukum itu sendiri secara teoritis, cakrawalanya berkembang luas dan komprehensive. Pemanfaatan penggabungan ilmu hukum dengan filsafat hukum adalah politik hukum, sebab politik hukum lebih praktis, fungsional dengan cara menguraikan pemikiran teleologis konstruktif yang dilakukan di dalam hubungannya dengan pembentukan hukum dan penemuan hukum yang merupakan kaidah abstrak yang berlaku umum, sedangkan penemuan hukum merupakan penentuan kaidah konkrit yang berlaku secara khusus.

Di dalam memahami adanya hubungan ilmu hukum dengan Hukum Positif, menyangkut hukum normatif diperlukan telaah terhadap unsur-unsur hukum. Unsur hukum mencakup unsur ideal dan rational. Unsur ideal mencakup hasrat susila dan ratio manusia yang menghasilkan asas-asas hukum, unsur riil mencakup kebudayaan, lingkungan alam yang menghasilkan tata hukum. Unsur ideal menghasilkan kaidah-kaidah hukum melalui filsafat hukum. Unsur riel menghasilkan tata hukum yang dalam hal ini dipengaruhi asas-asas hukum yang bertitik tolak dari bidang-bidang tata hukum tertentu dengan cara mengadakan 35 identifikasi kaidah-kaidah hukum yang telah dirumuskan di dalam perundangundangan tertentu (Soekanto, 1986: 16).

Kaedah hukum merupakan ketentuan, pedoman, perumusan pendapat, berisi kenyataan normatif bersifat memerintah, mengharuskan untuk ditaati agar tidak terjadi pelanggaran sehingga manusia terbebaskan dan sanksi. Hal ini yang mendasari munculnya aliran-aliran dan pandangan filsafat hukum misalnya:

1. Aliran Filsafat Hukum Kodrat

2. Aliran Historisme

3. Aliran Hukum Umum

4. Aliran Teori George Wilhelm Friederich Hegel

5. Aliran Teori Marx-Engels

6. Aliran Teori Jhering

7. Aliran Teori Relativisme

8. Aliran Teori Stammler (W. Friedmann, 1959: 23).

Indonesia sebagai negara hukum (Rechtsstaat) pada prinsipnya bertujuan untuk menegakkan perlindungan hukum (iustitia protectiva). Hukum dan cita hukum (Rechtidee) sebagai perwujudan budaya. Perwujudan budaya dan peradaban manusia tegak berkat sistem hukum, tujuan hukum dan cita hukum (Rechtidee) ditegakkan dalam keadilan yang menampilkan citra moral dan kebajikan adalah fenomena budaya dan peradaban. Manusia senantiasa berjuang menuntut dan membela kebenaran, kebaikan, kebajikan menjadi cita dan citra moral kemanusiaan dan citra moral pribadi 
manusia. Keadilan senantiasa terpadu dengan asas kepastian hukum (Rechtssicherkeit) dan kedayagunaan hukun (Zeweclcmassigkeit). Tiap makna dan jenis keadilan merujuk nilai dan tujuan apa dan bagaimana keadilan komutatif, distributif maupun keadilan protektif demi terwujudnya kesejahteraan lahir dan batin warga negara, yang pada hakikatnya demi harkat dan martabat manusia.

Hukum dan citra hukum (keadilan) sekaligus merupakan dunia nilai dan keseluruhannya sebagai fenomena budaya. Peranan filsafat hukum memberikan wawasan dan makna tujuan hukum sebagai cita hukum (rechtidee). Cita hukum adalah suatu apriori yang bersifat normatif sekaligus suatu apriori yang bersifat normatif sekaligus konstitutif, yang merupakan prasyarat transendental yang mendasari tiap Hukum Positif yang bermartabat, tanpa cita hukum (rechtidee) tak akan ada hukum yang memiliki watak normatif (Rouscoe Pound, 1972: 23).

Hukum berfungsi sebagai pelindungan kepentingan manusia, agar kepentingan manusia terlindungi, hukum harus dilaksanakan secara tegas dan adil. Pelaksanaan hukum dapat berlangsung normal, damai, tertib. Hukum yang telah dilanggar harus ditegakkan melalui penegakkan hukum. Penegakkan hukum menghendaki kepastian hukum, kepastian hukum merupakan perlindungan yustisiable terhadap tindakan sewenang-wenang. Masyarakat mengharapkan adanya kepastian hukum karena dengan adanya kepastian hukum masyarakat akan tertib, aman dan damai. Masyarakat mengharapkan manfaat dalam pelaksanaan penegakkan hukum. Hukum adalah untuk manusia, maka pelaksanaan hukum harus memberi manfaat, kegunaan bagi masyarakat jangan sampai hukum dilaksanakan menimbulkan keresahan di dalam masyarakat. Masyarakat yang mendapatkan perlakuan yang baik, benar akan mewujudkan keadaan yang tata tentram dan damai. Hukum dapat melindungi hak dan kewajiban setiap individu dalam kenyataan yang senyatanya, dengan perlindungan hukum yang kokoh akan terwujud tujuan hukum secara umum: ketertiban, keamanan, ketentraman, kesejahteraan, kedamaian, kebenaran, dan keadilan (Soejadi, 2003: 5).

Memperhatikan semua pembahasan dalam tulisan ini, bahwa keadilan dalam filsafat hukum itu tetap akan ada sepanjang usia pelaksanaan penegakan hukum dan akan di pegang teguh karena keadilan merupakan cita dan mengimbangi unsur lainnya yaitu kemanfaatan dan kepastian hukum. Pemahaman akan filsafat hukum benar akan dapat memjelaskan nilai dasar hukum secara filosofis dan sudah seharusnya semakin diperkuat oleh para-parah pihak yang kompeten sehingga membangun hukum yang sebenarnya.

\section{Kesimpulan dan Saran}

Filsafat ilmu Hukum memberikan prespektif bahwa keadilan diwujudkan dalam hukum. Filsafat hukum berupaya memecahkan persoalan, menciptakan hukum yang lebih sempurna, serta membuktikan bahwa hukum mampu memberikan penyelesaian persoalan-persoalan yang hidup dan berkembang di dalam masyarakat dengan menggunakan sistim hukum yang berlaku suatu masa, disuatu tempat sebagai Hukum Positif.

Tugas filsafat hukum masih relevan untuk menciptakan kondisi hukum yang sebenarnya, sebab tugas filsafat hukum adalah menjelaskan nilai-nilai, dasardasar hukum secara filosofis serta mampu memformulasikan cita-cita keadilan, ketertiban di dalam kehidupan yang relevan dengan kenyataankenyataan hukum yang berlaku, bahkan tidak menutup kemungkinan hukum menyesuaikan, guna memenhui kebutuhan perkembangan hukum pada suatu masa tertenu, suatu waktu dan pada suatu tempat. 
Rasa keadilan harus diberlakukan disetiap kehiduapn manusia yang terkait dengan masalah hukum, sebab hukum tertutama filsafat hukum menghendaki tujuan hukum tercapai yaitu: Mengatur pergaulan hidup secara damai, Mewujudkan suatu kedilan, Meciptakan kondisi masyarakat yang tertib, aman dan damai Hukum melindungi setiap kepentingan manusia dalam bermasyarakat, dan Meningkatkan kesejahteraan umum.

Rasa keadilan yang dirumuskan hakim mengacu pada pengertian-pengertian aturan baku yang dapat di pahami masyarakat dan berpeluang untuk dapat dihayati, karena rasa keadilan merupakan "soko guru" dari konsep-konsep "the rule of law". Hakim merupakan lambang dan benteng dari hukum jika terjadi kesenjangan rasa keadilan. Jika rasa keadilan hakim dan rasa keadilan masyarakat tidak terjadi maka semakin besar ketidakpeduliannya terhadap hukum, karena pelaksanaan hukum menghindari anarki.

Saran. Penjabaran fungsi filsafat hukum terhadap permasalahan keadilan merupakan hal yang sangat fundamental karena keadilan merupakan salah satu tujuan dan hukum yang diterapkan pada Hukum Positif. Hukum merupakan alat untuk mengelola masyarakat (Law as a tool of social engineering, menurut Roscoe Pound), pembangunan, penyempurna kehidupan bangsa, negara dan masyarakat demi terwujudnya rasa keadilan bagi setiap individu, yang berdampak positif bagi terwujudnya "kesadaran hukum". Ini merupakan cara untuk menjabarkan fungsi hukum yang masih relevan dengan kehidupan peraturan-perundang-undangan yang berlaku (Hukum Positif).

\section{REFERENSI}

Amin, M, (2017). Kebenaran hukum vs keadilan masyarakat. Diakses dari http://www.Palubukapam,net /artikel/186-kebenaran hukum-vs-keadilan-masyarakat.html, diakses 9 Agustus 2018.

Darmodiharjo, D., \& Shidarta, (2006). Pokok-pokok filsafat hukum apa dan bagaimana hukum di indoensia. Jakarta: PT. Gramedia Pustaka Utama

Mertokusumo, S. (1988). Mengenal hukum, suatu pengantar, Yogyakarta: Liberty.

Soekanto, S. (1986). Renungan tentang hukum, Jakarta: CV. Rajawali.

Soejadi. (2003). Relfleksi mengenai hukum dan keadilan, aktualisasinya di Indonesia, Yogyakarta: Universitas Gadjah Mada. 